\title{
The Impacts of Covid-19 Pandemy on Technology Literacy Usage on Students Learning Experience
}

\author{
Mezia Kemala Sari ${ }^{1}$, Efri Yoni ${ }^{2}$ \\ ${ }^{1-2}$ Faculty of Education and Teacher Training, Muhammadiyah University of West Sumatra, Padang, 25172, \\ meziakemalasari@umsb.ac.id
}

Received: 31/12/2020.

Reviewed: 06/04/2021.

Published: 28/04/2021.

Copyright (C2021 by the author (et al) and Jurnal Sosial Humaniora (JSH)

*This work is licensed under the Creative

Commons Attribution International License (CC

BY 4.0).

http://creativecommons.org/licenses/by/4.0/ Open Access

\begin{abstract}
Subject Area: Education
Abstract

This study aims at investigating the positive impact of the Covid-19 pandemic which has changed the learning process from offline to online. The research focuses on the use of the internet as a means of technological literacy which is the reference for research on student learning experiences. This study uses a comparative descriptive method by comparing internet usage before and during the pandemic related to the learning process. A structural questionnaire link using google form was sent to students through WhatsApp. A total of 36 students provided complete information regarding the survey. The simple percentage distribution was used to assess the learning status of the study participants. The results showed that there was a significant increase in the use of technology and internet literacy where downloading, uploading, attending workshops, webinars, and online competitions increased in frequency by using many online learning applications. The positive impact that can be seen is the increase in digital skills of students and lecturers as shown by their creativity and willingness to be more active, which of course supports online learning.
\end{abstract}

Keywords: positive impact, internet, literacy digital, learning experience.

\section{Introduction}

The COVID-19 pandemic has disrupted the normal functioning of various activities across the world, including learning and education. The shift towards online education during the pandemic of COVID19 has led many studies to focus on perceived learning outcomes and student satisfaction in this new learning environment. Since December 2019, a series of unexplained pneumonia cases have been reported in Wuhan, China. On 12 January 2020, the World Health Organization (WHO) temporarily named this new virus-like the 2019 novel coronavirus (2019-nCoV). On 11 February 2020, the WHO officially named the disease caused by the 2019-nCoV as coronavirus disease (COVID-19). The COVID-19 pandemic is spreading all over the world, especially in China (Sun, Lu, Xu, Sun, \& Pan, 2020).

This pandemic caused major changes in countries. The impact of the change is evident in several sectors. One of them is education. China and other contries (including Indonesia) had closed their schools. As a huge challenge to education systems, this pandemic affects the learning system since the school has been closed purposively. Since it has spread to the world of education, the Ministry of Education and 
Culture (MOEC) of Indonesia is ready with all scenarios, including encouraging online learning for students (Abidah, Hidaayatullaah, Simamora, Fehabutar, \& Mutakinati, 2020).

This change creates the distinctive rise of e-learning, whereby teaching is undertaken remotely and on digital platforms. In some countries, this system may be new because they used to study with the traditional method of learning. Blended learning has recently become more familiar since technology has been existed to support learning. Classroom learning has also started using many creative activities by using technology. In addition to face-to-face classroom practices, and information technology-based gamified system with a range of online learning activities was presented to students as support material. (Tsay, Kofinas, \& Luo, 2018).

It attempts to provide a new perspective through which the variety of literacy practices across different cultures can be viewed and from which the practical issues that arise in specific literacy campaigns and programs can be approached (Julien, 2017). The transition to online learning by schools, colleges, and universities has received considerable attention although online learning is not a new thing. It means, before the pandemic, we also have become familiar with the internet and digital literacy in form of many activities which use internet.

The problem is not all of the students in this world, especially Indonesian students can follow the new system of learning experience due to the outbreak of Covid-19. Since, students need to be guided and stimulated before, during, and after learning material in the classroom. It has been an assignment for all of the education circumstance. So, it can be a challenge for the teacher and lecturer to be creative to attract attention. It purposes to increase their curiosity and attention to the topic of learning (Sari \& Sari, 2019).

This changing habit before the pandemic and during the pandemic create a new reason to use digital literacy and many platforms of learning that available freely. With the diffusion of easy-to-use Web 2.0 tools, such as podcasts, blogs, and wikis, e-learning has become a popular mechanism for individual training. The problem is the individual's capability. individual's level of digital literacy affects her performance through its impact on her performance and effort expectations. The digital literacy on users' performance and effort expectations have a significant relation. In short, individual digital literacy facilitates the use of e-learning and should be considered when examining the impact of the latter on performance (Mohammadyari \& Singh, 2015).

Based on the changing phenomena that happen nowadays, this research aims to see the changing habit of the student in learning online by comparing it, then investigate the-impact of learning activities from offline to online. The research focuses on the technological literacy of internet users which is the reference for research on student learning experiences in West Sumatra, Indonesia.

\section{Literature Review}

The education changing has taken the attention of many researchers especially in observing how the learning is done during the pandemic. Numerous ways are noted in the literature to motivate and engage students including lecturer enthusiasm, interactive classes, engaging students through group activities, and 
using effective teaching methods that promote active learning in offline activities. These conditions must be different and difficult to maintain when teaching is restricted to online sessions.

Finding the impact, the perspective, and the new method of learning must attract the researcher's attention now. Many researchers attempt to find, compare, reveal and criticize how the learning run all over the world during the outbreak time. Elmer et.al tries to discuss future strategies on how to combine on-site teaching with online courses in Switzerland. The research considers how mental health and social contact affect learning because of isolation. Their results indicate the importance of considering social contacts in students' mental health and offer starting points to identify and support students at higher risk of social isolation and negative psychological effects during the COVID-19 pandemic (Elmer, Mepham, \& Stadtfeld, 2020).

Another research attempted to reveal the effective things to be changed to support online learning. Like the normal classroom subjects, teaching should include varied assignments and work that puts COVID-19 in a global and historical context. Many factors should be rearranged such as constructing curricula, designing student assessment which helps teachers and lecturers to focus. Finally, this viewpoint suggests flexible ways to repair the damage to students' learning trajectories once the pandemic is over and gives a list of resources. (Daniel, 2020; Toquero, 2020)

Moreover, another researcher, Dhawan, was concerned with the learning system in India. He stated that educational institutions (schools, colleges, and universities) in India are currently based only on traditional methods of learning, that is, they follow the traditional set up of face-to-face lectures in a classroom. Although many academic units have also started blended learning, still a lot of them are stuck with old procedures. The changing of the learning system is not easy there. This situation challenged the education system across the world and forced educators to shift to an online mode of teaching overnight. Many academic institutions that were earlier reluctant to change their traditional pedagogical approach had no option but to shift entirely to online teaching-learning. The article includes the importance of online learning and Strengths, Weaknesses, Opportunities, \& Challenges (SWOC) analysis of e-learning modes in a time of crisis which reveals the important thing related to the quality of learning (Dhawan, 2020)

Covid-19 affected higher educational institutions not just in Wuhan, China where the virus originated but all other higher educational institutions in China. Chinese, as the first country attacked by Covid-19, has made use of different modes of learning, including online-learning based on different platforms to achieve the goal suggested by the Ministry of Education in China, "suspending classes without suspending learning," since middle February (Wang \& Zhao, 2020).

Another research done in Ghana was aimed at accessing the impact of Covid-19 on learning. The study employed a descriptive survey design in which 11 item Likert-scale type of questionnaires was administered to 214 respondents mainly students in the second cycle and tertiary institutions of Ghana. The result showed that some students encounter challenges in the closedown of schools due to the outbreak of the pandemic Covid-19. Students are unable to study effectively from the house that make the online system of learning very ineffective. Furthermore, parents are incapable of assisting their $\mathrm{c}$ on children on how to access the online learning platform, neither can they entirely supervise the learning of their children at home 
without any complications. It came to light that the pandemic has harmed their learning as many of them are not used to effectively learn by themselves. As the suggestion, the study recommends that students should be introduced to innovative and offline e-learning platforms to supplement classroom teaching and learning and also be of benefit to students who may not have access to internet connectivity (OwusuFordjour, Koomson, \& Hanson, 2020).

In Indonesia, dramatic changes also happen. The government's move is right to issue a policy to the public not to have any activity outside the home and all work is carried out from home in order to avoid and break the chain of the spread of Covid-19 (Zaharah \& Kirilova, 2020). Students in Indonesia also face so many difficulties due to the changing of learning experience. One of the solutions by the government of Indonesia is giving free learning internet quota cooperated with some available learning platforms.

Another research has been conducted in Denmark which suggests that online learning has been shown to increase retention of information and take less time, meaning the changes coronavirus has caused might be here to stay. While countries are at different points in their COVID-19 infection rates, there are currently more than 1.2 billion children in 186 countries worldwide affected by school closures due to the pandemic. On the other hand, whether it is language apps, virtual tutoring, video conferencing tools, or online learning software, there has been a significant surge in usage since COVID-19 (Cathy Li, 2020).

Further research has been conducted to assess the impact of lockdown amidst COVID-19 on undergraduate and postgraduate learners of various colleges and universities of West Bengal. By using an online survey, questionnaire link via 'Google form' was sent to students through WhatsApp and E-mail. A total of 232 students provided complete information regarding the survey. The result is students have been facing various problems related to depression, anxiety, poor internet connectivity, and unfavorable study environment at home. This result suggests targeted interventions to create a positive space for study among students from the vulnerable section of society by using the strategies which are urgently needed to build a resilient education system in the state that will ensure to develop the skill for employability and the productivity of the young minds (Kapasia et al., 2020).

\section{Methodology}

The descriptive phenomenology design was used for this study. The descriptive research is a research conducted to answer more abstract or concrete question. This type can also generate to mindless gathering or abstract empiricism (Broadhurst, Holt, \& Doherty, 2012). This design was selected because the focus of the study was to describe the use of the internet as the source of digital literacy. This study uses a comparative descriptive method by comparing the use of internet as the literacy digital source for the learning process before and during the pandemic. A structural questionnaire link using 'Google form' was sent to students' through WhatsApp and E-mail. A total of thirty six students provided complete information regarding the survey. They were English Education Study Program of Faculty of Education and Teacher Training of Muhammadiyah University of West Sumatra. 
The simple percentage distribution was used to assess the learning status of the study participants. This procedure was appropriate to implement during the COVID-19 pandemic when participants were in their homes and the only means of contacting them was through other research participants' assistance. Upon reaching a participant via google form that we shared via WhatsApp group, the participant was briefed about the purpose of the study, and his or her consent was sought before he or she was interviewed.

\section{Result and Discussion}

One of the interesting things in the learning experience during a pandemic is the surge or increase in technological literacy or the usability of students to several online learning applications that automatically force them to use technology and internet networks sustainably. Moreover, the government has provided a free quota of internet learning for online learning. Several learning applications have also become in great demand to replace face-to-face learning. This shows the efforts of lecturers, government, and students to stay productive together even during a pandemic.

Table 1. The Frequency of Learning Experience Activities

\begin{tabular}{|c|c|c|c|c|c|c|c|c|c|c|c|c|}
\hline \multirow{2}{*}{$\begin{array}{l}\text { Frequency of } \\
\text { Activity } \\
\text { (per week on } \\
\text { average) }\end{array}$} & \multicolumn{6}{|c|}{ Before Pandemy (percentage) } & \multicolumn{6}{|c|}{ During Pandemy (percentage) } \\
\hline & $\begin{array}{c}0 \\
0-2 \\
\text { hour }\end{array}$ & $\begin{array}{c}1 \\
2-4 \\
\text { hour }\end{array}$ & $\begin{array}{c}2 \\
4-6 \\
\text { hour }\end{array}$ & $\begin{array}{c}3 \\
6-8 \\
\text { hour }\end{array}$ & $\begin{array}{c}4 \\
8-10 \\
\text { hour }\end{array}$ & $\begin{array}{c}5 \\
>10 \\
\text { hour }\end{array}$ & $\begin{array}{c}0 \\
0-2 \\
\text { hour }\end{array}$ & $\begin{array}{c}1 \\
2-4 \\
\text { hour }\end{array}$ & $\begin{array}{c}2 \\
4-6 \\
\text { hour }\end{array}$ & $\begin{array}{c}3 \\
6-8 \\
\text { hour }\end{array}$ & $\begin{array}{c}4 \\
8-10 \\
\text { hour }\end{array}$ & $\begin{array}{c}5 \\
>10 \\
\text { hour }\end{array}$ \\
\hline $\begin{array}{l}\text { Studying by } \\
\text { using internet } \\
\text { connection }\end{array}$ & 2.78 & 8.33 & 50 & 30.56 & 5.56 & 2.78 & 2.78 & 2.78 & 16.67 & 5.56 & 38.89 & 33.33 \\
\hline $\begin{array}{l}\text { Upload } \\
\text { learning } \\
\text { content }\end{array}$ & 11.11 & 25 & 33.33 & 27.78 & 0 & 2.78 & 0 & 8.33 & 13.89 & 19.4 & 36.11 & 22.22 \\
\hline $\begin{array}{l}\text { Download } \\
\text { learning } \\
\text { content }\end{array}$ & 2.78 & 13.89 & 58.33 & 13.89 & 8.33 & 2.78 & 0 & 8.33 & 5.56 & 8.33 & 41.67 & 36.11 \\
\hline $\begin{array}{l}\text { Following } \\
\text { online } \\
\text { workshop or } \\
\text { webinar }\end{array}$ & 27.78 & 19.44 & 27.78 & 19.44 & 5.56 & 0 & 8.33 & 5.56 & 16.67 & $\begin{array}{l}33.3 \\
3\end{array}$ & 19.44 & 16.67 \\
\hline $\begin{array}{l}\text { Following } \\
\text { online event/ } \\
\text { competition }\end{array}$ & 36.11 & 16.67 & 38.89 & 0 & 8.33 & 0 & 22.2 & 8.33 & 44.44 & 11.1 & 13.89 & 0 \\
\hline
\end{tabular}

From the table above, we can see the changes in the percentage comparing the activities related to a learning experience about using the internet or digital literacy before the pandemic and during the pandemic.

1. Studying by using internet connection

Before the pandemic, the tendency for student learning was to use a traditional system using a projector media or a writing board. This is a routine way of learning on campus. The level of 
creativity of a lecturer is also seen from his ability to manage classes, making the atmosphere lively and passionate so that students understand more and are interested in learning. However, when the pandemic occurs, and we are all forced to learn from our homes, there are many changes. Based on the Table 1 above, there is an increase in frequency of using the internet on average for about 3-5 hours of learning per week to more than 10 hours per week. This is of course because all materials and sources must be searched on the internet.

2. Upload the content of the learning

Uploading assignments, lecture materials, and materials for students is an obligation. Many students also create YouTube accounts to store assignment files such as videos or power points instead of storing them on their cellphones which of course will use up a lot of memory capacity. As it can be seen in the table, the frequency of uploading learning content increase significantly from never to more often.

3. Download content of learning

Learning material as support is widely available on the internet, either provided by the lecturers themselves or referring to learning content that is widely available freely ranging from scientific articles, e-books, online libraries, and platforms that provide lecture materials freely. The table shows a significant increase in the activity of downloading material from the internet as a means of providing digital literacy.

4. Following online workshop or seminar

Before the pandemic, it was seen that the participants did not attend workshops or seminars very often due to the lack of access and opportunities or costs to travel to attend national to international seminars. Meanwhile, during the pandemic, there was an increase in the frequency of participant activities to take part in online workshops and seminars because of the easy access and flexibility to follow from home and at no cost.

5. Following online event or competition

Participating in competitions is also an indication of the positive impact of this pandemic. From the Table 1, it can be seen that there has been a significant increase in competion activities during the pandemic compared to before the pandemic.

The many changes that occurred in the learning experience between lecturers and students has had positive and negative impacts. We have been and are still going through the pandemic period, although it is starting to get better. The experience with online learning methods certainly brought changes despite complains and blaming the situation. We must get up and fight the situation and strive so that the teaching and learning process continues and it is not impossible to stimulate positive, pleasant situations.

Based on research results, some positive impacts of studying in the middle of this pandemic atmosphere in terms of digital literacy use are as follow: 
1. Increase the digital skills of students

Students feel a great impact when they are forced to be able to use and run several online learning support media such as: how to operate Zoom, Google Meet, Google Classroom, Google Form, and even use assessment media that must be introduced from the time of downloading, such as Kahoot, Quizizz, Mentimeter, and so on. Moreover, the use of YouTube also seems to have increased significantly. This raises a new positive attitude by the academic community towards the learning atmosphere. Even though it looks tough at first, when it has been undertaken, the online learning becomes interesting.

2. Increase willingness and active participation in online training and seminars.

Online seminars or webinars have become popular during the pandemic because many seminars or training activities could be followed even from home. As we all know, workshops or seminars are very important activities for both lecturers and students. Not all of us have the opportunity to be able to follow it. Before the pandemic, participating in training and seminars may costly, especially for those in the regions. To attend seminars or workshops on a national and international scale requires a lot of money, for example, such as training in international journal writing, writing textbooks, and so on. However, when the pandemic took place, the positive impact was felt by students who had ample opportunity to take part in national and international online training and workshops for free and from home using Zoom media, Cisco Webex, Google Meet, or live streaming Youtube. This must be very positive because even during the pandemic, we can still increase our knowledge through webinars and online workshops and even get official certificates.

3. Increase the spirit of competition

The online learning during the pandemic increased the spirit not only in academics but also in competition. Students get so many opportunities to compete even online. Precisely because it is online, many opportunities can be achieved. For example, for students of the English language education study program, there are many online competitions held by various parties ranging from campus levels to ministries. Contests in the form of video submissions such as speech competitions, master of ceremonies, poetry creation competitions, short story creation competitions, creative poster competitions, creative video competitions, photography competitions, and so on have emerged. It triggers the enthusiasm of the students to make more achievements. Moreover, they don't need to pay anything and even with the many free events, this is an encouragement. Another positive impact of this online competition is that they are also increasingly technology literate. For example, a competition to make creative posters and creative videos will force them to learn to create content and edit videos. Of course, this skill will be additional capital for them as the millennial generation who are required to master technology to work.

4. Increased enthusiasm for collaboration and network expansion

Students also get the many positive impacts by doing activities online frequently, namely increasing connections and getting acquainted with other students from various regions, especially with the ease of communication and community networks such as the WhatsApp group or telegram, 
which is owned by almost everyone today. This is what further proves that during this pandemic if it is addressed with a positive attitude, it will give result to a very positive condition directly or indirectly.

5. The learning process is more flexible

Independent learning, non face-to-face mode also has a positive impact on the effectiveness of learning. Although not very significant, from the results of observations, students think that online learning can be more effective because they can study anywhere. This proves that learning experiences during a pandemic can have a positive impact even though we are under conditions that are completely limited in space. However, since we are already in an era that is all internet-based and requires good digital literacy skills, everyone will inevitably feel an increase in digital capabilities directly or indirectly.

Moreover, e-Learning can also deliver substantial positive effects such as students are more engaged and able to develop 21st-century skills, lecturers have a more positive attitude toward their work and can provide more personalized learning, family interaction and parental involvement may increase, communities benefit from bridging the digital divide (The Positive Impact of eLearning, 2012).

\section{Conclusion}

This study focused on the online learning experience of college students in West Sumatra. The study concludes that there are some positive impacts of the Covid-19 pandemic in terms of technology literacy on students learning experience. The results show that some positive impacts of improvements like the changing of using digital skills of students, increased willingness and activeness to take part in online training and seminars, increased spirit of competition, increased enthusiasm for collaboration, added networks, and more flexible of the learning process. Also, the study concludes that lecturers and college students experience internet and digital literacy more comprehensively than before pandemic condition. It shows that the Covid19 pandemic can affect positive impacts if we see it from a different point of view as explained in the discussion. For the next research, as a suggestion, it will be more comprehensive to take a larger number of participants with a larger population to get more precise data and scientific results.

\section{References}

Abidah, A., Hidaayatullaah, H. N., Simamora, R. M., Fehabutar, D., \& Mutakinati, L. (2020). The Impact of Covid-19 to Indonesian Education and Its Relation to the Philosophy of "Merdeka Belajar." Studies in Philosophy of Science and Education. https://doi.org/10.46627/sipose.v1i1.9

Broadhurst, K., Holt, K., \& Doherty, P. (2012). What is Research design? Explanatory/descriptive research. Qualitative Social Work.

Cathy Li, F. L. (2020). The rise of online learning during the COVID-19 pandemic | World Economic Forum.

Daniel, S. J. (2020). Education and the COVID-19 pandemic. Prospects. https://doi.org/10.1007/s11125-020- 


\section{4-3}

Dhawan, S. (2020). Online Learning: A Panacea in the Time of COVID-19 Crisis. Journal of Educational Technology Systems. https://doi.org/10.1177/0047239520934018

Elmer, T., Mepham, K., \& Stadtfeld, C. (2020). Students under lockdown: Comparisons of students' social networks and mental health before and during the COVID-19 crisis in Switzerland. PLoS ONE. https://doi.org/10.1371/journal.pone.0236337

Julien, H. (2017). Digital Literacy in Theory and Practice. In Encyclopedia of Information Science and Technology, Fourth Edition. https://doi.org/10.4018/978-1-5225-2255-3.ch195

Kapasia, N., Paul, P., Roy, A., Saha, J., Zaveri, A., Mallick, R., ... Chouhan, P. (2020). Impact of lockdown on learning status of undergraduate and postgraduate students during COVID-19 pandemic in West Bengal, India. Children and Youth Services Review. https://doi.org/10.1016/j.childyouth.2020.105194

Mohammadyari, S., \& Singh, H. (2015). Understanding the effect of e-learning on individual performance: The role of digital literacy. Computers and Education. https://doi.org/10.1016/j.compedu.2014.10.025

Owusu-Fordjour, C., Koomson, C. K., \& Hanson, D. (2020). The impact of Covid-19 on learning-the perspective of the Ghananian student. European Journal of Education Studies.

Sari, M. K., \& Sari, L. R. (2019). THE EFFECT OF ANTICIPATION GUIDE STRATEGY ON STUDENTS' READING COMPREHENSION. Ta'dib. https://doi.org/10.31958/jt.v22i1.1434

Sun, P., Lu, X., Xu, C., Sun, W., \& Pan, B. (2020). Understanding of COVID-19 based on current evidence. Journal of Medical Virology. https://doi.org/10.1002/jmv.25722

The Positive Impact of eLearning. (2012). The Positive Impact of eLearning — 2012 Update. WHITE PAPER -Education Transformation.

Toquero, C. M. (2020). Challenges and Opportunities for Higher Education amid the COVID-19 Pandemic: The Philippine Context. Pedagogical Research. https://doi.org/10.29333/pr/7947

Tsay, C. H. H., Kofinas, A., \& Luo, J. (2018). Enhancing student learning experience with technologymediated gamification: An empirical study. Computers and Education. https://doi.org/10.1016/j.compedu.2018.01.009

Wang, C., \& Zhao, H. (2020). The Impact of COVID-19 on Anxiety in Chinese University Students. Frontiers in Psychology. https://doi.org/10.3389/fpsyg.2020.01168

Zaharah, Z., \& Kirilova, G. I. (2020). Impact of Corona Virus Outbreak Towards Teaching and Learning Activities in Indonesia. SALAM: Jurnal Sosial Dan Budaya Syar-I. https://doi.org/10.15408/sjsbs.v7i3.15104 